\title{
Fatty acid composition of Arctic and Antarctic macroalgae: indicator of phylogenetic and trophic relationships
}

\author{
Martin Graeve $^{1, *}$, Gerhard Kattner ${ }^{1}$, Christian Wiencke ${ }^{1}$, Ulf Karsten ${ }^{2}$ \\ ${ }^{1}$ Alfred Wegener Institute for Polar and Marine Research, Am Handelshafen 12, 27570 Bremerhaven, Germany \\ ${ }^{2}$ University of Rostock, Department of Biology, Institute of Aquatic Ecology, Albert-Einstein-Strasse 3, \\ 18051 Rostock, Germany
}

\begin{abstract}
The fatty acid composition of 6 Arctic and 14 Antarctic macroalgae species (Rhodophyta, Phaeophyta and Chlorophyta) from Kongsfjorden (west Spitsbergen, Arctic) and King George Island (Antarctic Peninsula) was investigated. The macroalgae were cultivated in nutrient-enriched seawater at low temperatures $\left(0\right.$ to $\left.5^{\circ} \mathrm{C}\right)$ and light conditions similar to natural irradiance. The most abundant fatty acids in the Arctic and Antarctic Rhodophyta were generally 20:5(n-3) and 16:0. The Arctic Palmaria palmata and the Antarctic Audouinella purpurea were characterised by very high proportions of 20:5(n-3) (67.3 and $60.3 \%$, respectively). Other important fatty acids were 16:1(n-7) and 20:4(n-6). Two species were dominated by 20:4(n-6) (Phycodrys rubens, 35.3\% and Delesseria lancifolia, 31.1\%). In Ptilota gunneri and Rhodymenia subantarctica, 16:1(n-7) accounted for 39.9 and $32.7 \%$, respectively. In the Phaeophyta, the major polyunsaturated fatty acids were 18:4(n-3), 20:5(n-3) and 20:4(n-6) followed by 18:3(n-3) and 18:2(n-6). The principal saturated fatty acid was 16:0. A high percentage of the uncommon monounsaturated fatty acid 16:1(n-5) (11.1\%) was found in Desmarestia muelleri sporophytes. Their gametophytes exhibited only traces of this component, but instead had double the amount of 18:2(n-6) and 18:3(n-3). The Arctic chlorophyte Prasiola crispa and the Antarctic Lambia antarctica had fatty acid compositions dominated by the polyunsaturated fatty acids 18:3(n-3) and 18:2(n-6). In L. antarctica, 18:1(n-7) was present at higher levels than 18:2(n6). The clear differences in fatty acid compositions of these 3 taxa are probably due to their different evolutionary position. The high proportions of 20:5(n-3) in the Rhodophyta reflect a 'marine'-like character and hence the phylogenetically oldest lineage. The Chlorophyta comprise the most 'modern' group and this is supported by primarily $\mathrm{C}_{18}$ unsaturated fatty acids typical of the vegetative tissue of higher plants. The fatty acid composition of the Phaeophyta support their intermediate position. The clear differences between the macroalgal taxa, and also variations between species, make fatty acids a potential tracer for studies of food-web interactions.
\end{abstract}

KEY WORDS: Macroalgae $\cdot$ Arctic $\cdot$ Antarctic $\cdot$ Fatty acids $\cdot$ Polyunsaturates $\cdot$ Biosynthesis

\section{INTRODUCTION}

Although they are restricted to continental shelves and coastal areas, benthic macroalgae play an important role in marine primary production. They serve as a food source for herbivores and detritivores, as well as

*E-mail: mgraeve@awi-bremerhaven.de nursery areas for fishes, crustaceans and other invertebrates (Smith 1981, Duggins et al. 1989). While these ecological functions are well-documented for temperate and tropical waters (Gaines \& Lubchenco 1982, Hawkins \& Hartnoll 1983), appropriate studies for polar regions are still rare (Iken et al. 1997, Iken 1999).

As reported for temperate and tropical habitats, the macrophytobenthos in the Antarctic often serves as a hard substratum for numerous, mainly sessile, organisms 
supporting the development of complex benthic communities (Klöser et al. 1996). Some of the few observations on the trophodynamics of Antarctic macroalgal forests demonstrate a high abundance of herbivores grazing directly on the plants. A small number of predators such as fishes hunt for vagile invertebrates associated with macroalgae and for sessile animals (Amsler et al. 1998, Iken 1999). These studies indicate manifold ecological interactions between the underwater flora and fauna in Antarctica, but little information is available, for example, on the fate of benthic primary production and on the trophic relationships (Iken et al. 1997, Iken 1999, Graeve et al. 2001). While few ecological investigations have been carried out in Antarctic waters, similar data on trophic relationships of Arctic macroalgae are lacking.

In recent years, various studies on the ecological interactions within the Arctic and Antarctic pelagic food web have successfully used fatty acids as trophic markers to answer the question 'Who is feeding on whom?' (e.g. Graeve et al. 1994a,b, 1997, Phleger et al.
1998, Nelson et al. 2000, 2001). Some data on the fatty acid composition of macroalgae from temperate and tropical waters have also been reported (Arao \& Yamada 1989, Aknin et al. 1992, Banaimoon 1992, Jones \& Harwood 1992, Khotimchenko 1998), although similar information on polar species are not available.

Here we determined, for the first time, the fatty acid composition of macroalgae from Antarctic and Arctic waters, to identify specific fatty acids characteristic for different macroalgal taxa and even species. For the first time, fatty acids have been used to reveal ther potential for the identification of phylogenetic relationships. These basic data could serve as trophic markers in studies on polar plant-herbivore interactions.

\section{MATERIALS AND METHODS}

Algal material. The locations of and ecological information on the macroalgal species studied are pre-

Table 1. Location and habitat of the investigated Arctic and Antarctic macroalgae. E: endemic; -: not endemic

\begin{tabular}{|c|c|c|c|}
\hline Species & Arctic/Antarctic & Habitat (depth) & Origin \\
\hline \multicolumn{4}{|l|}{ Rhodophyta } \\
\hline \multicolumn{4}{|l|}{ Ceramiales } \\
\hline Delesseria lancifolia (J. D. Hooker) J. Agardh & Ant & Sublittoral (5-30 m) & - \\
\hline Georgiella confluens (Reinsch) Kylin & Ant & Sublittoral (5-25 m) & E \\
\hline Myriogramme smithii (J. D. Hooker et Harvey) Kylin & Ant & Sublittoral (8-45 m) & - \\
\hline Neuroglossum ligulatum (Reinsch) Skottsberg & Ant & Sublittoral (0-10 m) & E \\
\hline Pantoneura plocamioides Kylin \& Skottsberg & Ant & Sublittoral (2-45 m) & E \\
\hline Phycodrys rubens (Linnaeus) Batters & Arc & Sublittoral (12-18 m) & E \\
\hline Ptilota gunneri Silva, Maggs \& L. M. Irvine & Arc & sublittoral (12-15 m) & - \\
\hline \multicolumn{4}{|l|}{ Palmariales } \\
\hline Devaleraea ramentacea (Linnaeus) Guiry & Arc & Eulittoral to sublittoral $(0-7 \mathrm{~m})$ & E \\
\hline Palmaria decipiens (Reinsch) Ricker & Ant & Eulittoral to sublittoral $(0-30 \mathrm{~m})$ & E \\
\hline Palmaria palmata (Linnaeus) Greville & Arc & Sublittoral $(2-10 \mathrm{~m})$ & - \\
\hline \multicolumn{4}{|l|}{ Gigartinales } \\
\hline Gigartina skottsbergii Setchell \& Gardner & Ant & Tide pools, sublittoral $(0-30 \mathrm{~m})$ & - \\
\hline Gymnogongrus turquetii Hariot & Ant & Eulittoral, sublittoral $(0-30 \mathrm{~m})$ & - \\
\hline \multicolumn{4}{|l|}{ Acrochaetiales } \\
\hline Audouinella purpurea (Lightfoot) Woelkerling & Ant & Eulittoral, sublittoral & - \\
\hline \multicolumn{4}{|l|}{ Rhodymeniales } \\
\hline Hymenocladiopsis crustigena Moe & Ant & Sublittoral (2-30 m) & E \\
\hline Rhodymenia subantarctica Ricker & Ant & Sublittoral (5-25 m) & - \\
\hline \multicolumn{4}{|l|}{ Phaeophyta } \\
\hline \multicolumn{4}{|l|}{ Desmarestiales } \\
\hline Desmarestia antarctica Moe \& Silva & Ant & Sublittoral (2-20 m) & E \\
\hline Desmarestia muelleri Ramirez \& Peters & sub-Ant & Sublittoral (2-20 m) & - \\
\hline \multicolumn{4}{|l|}{ Laminariales } \\
\hline Laminaria solidungula J. Agardh & Arc & Sublittoral (12-18 m) & $\mathrm{E}$ \\
\hline \multicolumn{4}{|l|}{ Chlorophyta } \\
\hline \multicolumn{4}{|l|}{ Halimedales } \\
\hline Lambia antarctica (Skottsberg) Delépine & Ant & Eulittoral, tide pools & $\mathrm{E}$ \\
\hline \multicolumn{4}{|l|}{ Prasiolales } \\
\hline Prasiola crispa (Lightfoot) Kützing & Arc & Supralittoral & - \\
\hline
\end{tabular}


sented in Table 1. Macroalgal material was collected in Kongsfjorden (Ny-Ålesund, Spitsbergen, Arctic, 78 56' N, $11^{\circ} 56^{\prime} \mathrm{E}$ ) between 1996 and 1998, and on King George Island, Antarctica $\left(62^{\circ} 12^{\prime} \mathrm{S}, 58^{\circ} 58^{\prime} \mathrm{W}\right)$, between 1986 and 1994. In the laboratory at Bremerhaven, macroalgae were cultivated at 0 to $5^{\circ} \mathrm{C}$ in 1 to $5 \mathrm{l}$ glass beakers containing aerated membrane-filtered North Sea water (Sartorius Sartobran II, $0.2 \mu \mathrm{m}$ ) enriched with Provasoli's ES nutrients (Provasoli 1968). The media were replaced every $2 \mathrm{wk}$ to avoid nutrient limitation. The cultures were illuminated with cool-white fluorescent neon tubes (Osram L58/W19) at photon fluence rates of 20 to $50 \mu \mathrm{mol}$ photons $\mathrm{m}^{-2} \mathrm{~s}^{-1}$ (Wiencke 1990).

All Rhodophyta samples were from tetrasporophytic plants. For the Phaeophyta, Laminaria solidungula samples were taken from young, mid-aged and old sporophytic tissues, and sporophytes and gametophytes were analysed from Desmarestia muelleri. As the life histories of the studied chlorophytes were unknown, the samples could not be further specified.

Fatty acid analysis. Samples were analysed in duplicate or triplicate. The macroalgal tissues were homogenised and extracted in dichloromethane/methanol (2:1; v:v) according to Folch et al. (1957). For gas liquid chromatographic analysis of the fatty acid composition, aliquots of the extracted samples were taken. Methyl esters of the fatty acids were prepared by transesterification with $3 \%$ concentrated sulphuric acid in methanol for $4 \mathrm{~h}$ at $80^{\circ} \mathrm{C}$. After their extraction with hexane, their composition was analysed with a Chrompack gas liquid chromatograph (Chrompack 9000) on a capillary column $(30 \mathrm{~m} \times 0.25 \mathrm{~mm}$; film thickness: $0.25 \mu \mathrm{m}$; liquid phase: DB-FFAP) using temperature programming according to the method of Kattner \& Fricke (1986). Fatty acids were identified with commercially available standard mixtures and also by using a HP 5973 GC-MSDSystem. Averaged data of the individual fatty acids are expressed as a mass percentage of total fatty acids.

\section{RESULTS}

\section{Rhodophyta}

The fatty acid composition of the Arctic and Antarctic Rhodophyta are summarised in Tables $2 \& 3$. The individual species belong to 5 orders. All species were dominated by only a few fatty acids. They were all rich in $16: 0$ (16.9 to $37.7 \%$ ), and most of the species were also rich in 20:5(n-3) (24.2 to $67.3 \%$ ). Extraordinarily high levels of 20:5(n-3) were determined in the Arctic Palmaria palmata (Palmariales) (67.3\%) and the Ant-

Table 2. Fatty acid composition (mass \%) of Arctic (Arc) and Antarctic (Ant) Rhodophyta (Ceramiales). SAFA: sum of saturated fatty acids; MUFA: sum of monounsaturated fatty acids; PUFA: sum of polyunsaturated fatty acids; -: not detected

\begin{tabular}{|c|c|c|c|c|c|c|c|}
\hline $\begin{array}{l}\text { Fatty } \\
\text { acids }\end{array}$ & $\begin{array}{l}\text { Phycodrys } \\
\text { rubens } \\
\text { (Arc) }\end{array}$ & $\begin{array}{c}\text { Ptilota } \\
\text { gunneri } \\
\text { (Arc) }\end{array}$ & $\begin{array}{c}\text { Delesseria } \\
\text { lancifolia } \\
\text { (Ant) }\end{array}$ & $\begin{array}{c}\text { Georgiella } \\
\text { confluens } \\
\text { (Ant) }\end{array}$ & $\begin{array}{l}\text { Myriogramme } \\
\text { smithii } \\
\text { (Ant) }\end{array}$ & $\begin{array}{c}\text { Neuroglossum } \\
\text { ligulatum } \\
\text { (Ant) }\end{array}$ & $\begin{array}{c}\text { Pantoneura } \\
\text { plocamioides } \\
\text { (Ant) }\end{array}$ \\
\hline $14: 0$ & 3.4 & 4.9 & 3.3 & 2.7 & 1.3 & 2.4 & 1.0 \\
\hline $15: 0$ & 0.5 & 0.4 & 0.5 & - & 0.2 & 0.2 & 0.6 \\
\hline $16: 0$ & 28.0 & 27.9 & 37.7 & 16.9 & 27.5 & 27.8 & 33.7 \\
\hline $16: 1(n-7)$ & 17.9 & 39.9 & 13.5 & 10.6 & 0.6 & 6.5 & 1.7 \\
\hline $16: 1(n-5)$ & 0.4 & 0.3 & - & - & - & - & 2.5 \\
\hline $16: 2(n-4)$ & 0.3 & 1.0 & - & 3.2 & - & - & - \\
\hline $16: 3(n-4)$ & 0.5 & 0.6 & - & 5.9 & - & - & - \\
\hline $16: 4(n-1)$ & 0.7 & 0.7 & - & 5.0 & - & 0.6 & 13.1 \\
\hline $18: 0$ & 0.6 & 1.1 & 0.8 & - & 0.3 & 0.3 & - \\
\hline $18: 1(n-9)$ & 3.6 & 5.3 & 5.3 & 3.2 & 1.4 & 4.3 & 5.7 \\
\hline $18: 1(n-7)$ & 3.2 & 2.0 & 2.2 & 3.9 & 5.6 & 11.6 & 2.6 \\
\hline $18: 2(n-6)$ & 0.5 & 2.6 & 0.3 & 0.7 & 1.7 & 1.7 & 0.6 \\
\hline $18: 3(n-3)$ & - & 0.4 & - & 1.2 & - & - & - \\
\hline $18: 4(n-3)$ & - & 1.9 & - & 2.6 & - & - & - \\
\hline $20: 4(n-6)$ & 35.3 & 0.9 & 31.1 & 1.9 & 13.0 & 7.7 & 12.6 \\
\hline $20: 4(n-3)$ & - & - & - & - & - & - & - \\
\hline $20: 5(n-3)$ & 4.8 & 9.4 & 4.4 & 40.9 & 48.3 & 35.3 & 25.9 \\
\hline $22: 6(n-3)$ & 0.3 & 0.6 & 1.0 & 1.3 & - & 1.5 & - \\
\hline SAFA & 31.9 & 33.2 & 41.6 & 19.7 & 29.1 & 30.4 & 35.3 \\
\hline MUFA & 25.1 & 47.5 & 20.9 & 17.7 & 7.6 & 22.4 & 12.6 \\
\hline PUFA & 42.4 & 18.1 & 36.8 & 62.6 & 63.0 & 46.8 & 52.2 \\
\hline$(n-6)$ FA & 35.8 & 3.5 & 31.4 & 2.6 & 14.7 & 9.4 & 13.2 \\
\hline$(n-3)$ FA & 5.1 & 12.3 & 5.4 & 46.0 & 48.3 & 36.8 & 25.9 \\
\hline$(n-3) /(n-6)$ & 0.1 & 3.5 & 0.2 & 17.6 & 3.3 & 3.9 & 2.0 \\
\hline
\end{tabular}


Table 3. Fatty acid composition (mass \%) of Arctic (Arc) and Antarctic (Ant) Rhodophyta. SAFA: sum of saturated fatty acids; MUFA: sum of monounsaturated fatty acids; PUFA: sum of polyunsaturated fatty acids; - not detected

\begin{tabular}{|c|c|c|c|c|c|c|c|c|}
\hline \multirow{2}{*}{$\begin{array}{l}\text { Fatty } \\
\text { acids }\end{array}$} & \multicolumn{3}{|c|}{ Palmariales } & \multicolumn{2}{|c|}{ Gigartinales } & \multirow{2}{*}{$\begin{array}{c}\text { Acrochaetiales } \\
\text { Audouinella } \\
\text { purpurea } \\
\text { (Ant) }\end{array}$} & \multicolumn{2}{|c|}{ Rhodymeniales } \\
\hline & $\begin{array}{c}\text { Devaleraea } \\
\text { ramentacea } \\
(\mathrm{Arc})\end{array}$ & $\begin{array}{l}\text { Palmaria } \\
\text { palmata } \\
\text { (Arc) }\end{array}$ & $\begin{array}{l}\text { Palmaria } \\
\text { decipiens } \\
\text { (Ant) }\end{array}$ & $\begin{array}{l}\text { Gymnogongrus } \\
\text { turquetii } \\
\text { (Ant) }\end{array}$ & $\begin{array}{c}\text { Gigartina } \\
\text { skottsbergii } \\
\text { (Ant) }\end{array}$ & & $\begin{array}{l}\text { Rhodymenia } \\
\text { subantarctica } \\
\text { (Ant) }\end{array}$ & $\begin{array}{c}\text { Hymenocladi- } \\
\text { opsis crustigena } \\
\text { (Ant) }\end{array}$ \\
\hline $14: 0$ & 9.8 & 5.7 & 9.4 & 1.9 & 2.2 & 1.5 & 7.5 & 3.5 \\
\hline $15: 0$ & 0.6 & - & 0.5 & 0.2 & 0.4 & - & - & 0.5 \\
\hline $16: 0$ & 25.5 & 19.4 & 20.9 & 29.4 & 28.4 & 23.6 & 20.5 & 30.4 \\
\hline $16: 1(n-7)$ & 9.0 & 0.3 & 2.8 & 3.1 & 5.5 & 0.9 & 32.7 & 4.4 \\
\hline $16: 1(n-5)$ & - & - & - & - & - & - & - & 0.3 \\
\hline $16: 2(n-4)$ & 0.4 & - & - & - & 0.4 & - & 1.8 & 0.6 \\
\hline $16: 3(n-4)$ & - & - & - & 0.1 & 0.5 & - & - & 0.5 \\
\hline $16: 4(n-1)$ & 0.4 & - & - & - & 0.5 & - & 0.7 & 1.4 \\
\hline $18: 0$ & 1.1 & 0.4 & 0.9 & 0.5 & 0.8 & - & 1.6 & 0.6 \\
\hline $18: 1(n-9)$ & 7.5 & 2.1 & 7.0 & 3.3 & 10.7 & 2.0 & 12.5 & 3.9 \\
\hline $18: 1(n-7)$ & 3.1 & 3.2 & 4.8 & 1.5 & 2.5 & 1.6 & 4.8 & 1.7 \\
\hline $18: 2(n-6)$ & 3.4 & 0.5 & 0.4 & 3.6 & 0.7 & 0.6 & 0.9 & 3.4 \\
\hline $18: 3(n-3)$ & 4.1 & - & 0.2 & - & - & - & 1.1 & 0.8 \\
\hline $18: 4(n-3)$ & 6.7 & - & 0.4 & - & - & - & 4.1 & 1.8 \\
\hline $20: 4(n-6)$ & 1.9 & 1.1 & 2.2 & 11.5 & 22.2 & 9.4 & 1.0 & 8.5 \\
\hline $20: 4(n-3)$ & 0.6 & - & - & - & - & - & - & - \\
\hline $20: 5(n-3)$ & 24.2 & 67.3 & 49.8 & 44.3 & 25.2 & 60.3 & 10.8 & 37.3 \\
\hline $22: 6(n-3)$ & 1.6 & - & 0.7 & 0.5 & - & - & - & 0.5 \\
\hline SAFA & 35.9 & 25.1 & 30.7 & 31.5 & 31.0 & 25.1 & 28.0 & 34.3 \\
\hline MUFA & 19.5 & 5.6 & 14.7 & 8.0 & 18.7 & 4.5 & 50.0 & 10.3 \\
\hline PUFA & 43.3 & 68.9 & 53.7 & 60.0 & 49.4 & 70.4 & 20.4 & 54.8 \\
\hline$(n-6)$ FA & 5.3 & 1.6 & 2.6 & 15.1 & 22.9 & 10.1 & 1.9 & 11.9 \\
\hline$(n-3)$ FA & 37.2 & 67.3 & 51.1 & 44.8 & 25.2 & 60.3 & 15.9 & 40.3 \\
\hline$(n-3) /(n-6)$ & 7.0 & 42.2 & 19.9 & 3.0 & 1.1 & 6.0 & 8.3 & 3.4 \\
\hline
\end{tabular}

arctic Audouinella purpurea (Acrochaetiales) (60.3\%). Low percentages of 20:5(n-3) were found in the Antarctic Rhodymenia subantarctica and in 3 species of the order Ceramiales ( 2 species were from the Arctic [Phycodrys rubens and Ptilota gunneri] and 1 was from Antarctica [Delesseria lancifolia]). These 4 species were richer in 16:1(n-7), with the highest levels of $39.9 \%$ in $P$. gunneri and $32.7 \%$ in $R$. subantarctica. The fatty acid compositions of the 2 species with lower levels of 20:5(n-3) and 16:1(n-7) were dominated by $20: 4(n-6)$, which accounted for $35.3 \%$ in the Arctic Phycodrys rubens and $31.1 \%$ in the Antarctic D. lancifolia, both belonging to the order Ceramiales. A higher percentage of 20:4(n-6) was also found in Gigartina skottsbergii [22.2\%: similar to the percentage of 20:5(n-3)]. A special feature of the Antarctic Pantoneura plocamioides was the high level of 16:4(n-1). Generalising, mainly 4 major fatty acids were detected in the Rhodophyta: 16:0, 20:5(n-3), 16:1(n-7) and 20:4(n-6). In addition, the fatty acids 14:0, 18:1(n-9), 18:1(n-7) and $18: 4(n-3)$ were found in proportions of 5 to $10 \%$. The ratios of the sums of the $(n-3)$ and (n-6) fatty acids [i.e. (n-3) and (n-6) families] covered a wide range. The ratio of the 20:5(n-3)-dominated species varied between 3 and 42.2 , whereas those species with a major contribution of 20:4(n-6) had ratios between 0.1 and 1.1.

\section{Phaeophyta}

The fatty acid composition of the Arctic and Antarctic Phaeophyta are presented in Table 4. The major fatty acids were $20: 5(\mathrm{n}-3)(20 \%$ on average) and 18:4(n-3) (19\%), followed by 16:0 (13\%) and 18:3(n-3) (13\%). The fatty acids 18:2(n-6), 18:1(n-9) and 14:0 varied between 4 and $10 \%$. The fatty acids 20:4(n-6) and 16:1(n-7), which exhibited high levels in some Rhodophyta species, occurred only in small amounts in the Phaeophyta. The fatty acids 16:0 and 20:5(n-3) were also less dominant compared to most of the Rhodophyta species. The ratios of the (n-3) and (n-6) fatty acid families were 2.1 to 4.0 , reflecting the dominance of 20:5(n-3) and 18:4(n-3). The comparison of young, mid-aged and old sporophytic tissue of the Arctic Laminaria solidungula showed a similar percentage for most fatty acids except 18:4(n-3), the relative abundance of which decreased with age and was mostly compensated by an increase in 20:5(n-3) (Table 4).

The sporophytes and gametophytes of the Antarctic Desmarestia muelleri exhibited almost similar fatty acid composition, but some conspicuous differences were found. Sporophytes contained $11.1 \%$ of $16: 1$ (n-5), but gametophytes contained only trace amounts 
Table 4. Fatty acid composition (mass \%) of Arctic (Arc) and Antarctic (Ant) Phaeophyta and Chlorophyta. SAFA: sum of saturated fatty acids; MUFA: sum of monounsaturated fatty acids; PUFA: sum of polyunsaturated fatty acids; -: not detected

\begin{tabular}{|c|c|c|c|c|c|c|c|c|}
\hline \multirow{5}{*}{$\begin{array}{l}\text { Fatty } \\
\text { acids }\end{array}$} & \multicolumn{6}{|c|}{ — Phaeophyta $\longrightarrow$} & \multicolumn{2}{|c|}{ Chlorophyta } \\
\hline & \multirow{2}{*}{\multicolumn{3}{|c|}{$\begin{array}{l}\text { Laminariales } \\
\text { Laminaria solidungula (Arc) }\end{array}$}} & \multicolumn{3}{|c|}{ Desmarestiales } & \multirow{4}{*}{$\begin{array}{c}\text { Halimedales } \\
\text { Lambia } \\
\text { antarctica (Ant) }\end{array}$} & \multirow{4}{*}{$\begin{array}{l}\text { Prasiolales } \\
\text { Prasiola } \\
\text { crispa (Arc }\end{array}$} \\
\hline & & & & \multirow{2}{*}{\multicolumn{2}{|c|}{$\begin{array}{c}\text { Desmarestia } \\
\text { muelleri (Ant) }\end{array}$}} & \multirow{3}{*}{$\begin{array}{c}\text { Desmarestia } \\
\text { antarctica (Ant) } \\
\text { S Sporophytes }\end{array}$} & & \\
\hline & \multirow[t]{2}{*}{ Young } & \multirow[t]{2}{*}{ Mid } & \multirow{2}{*}{ Old } & & & & & \\
\hline & & & & Sporophytes & Gametophytes & & & \\
\hline $14: 0$ & 5.3 & 6.3 & 5.2 & 5.9 & 3.7 & 4.8 & 5.0 & 1.5 \\
\hline $15: 0$ & - & 0.2 & 0.6 & - & 0.1 & 0.1 & 0.1 & - \\
\hline $16: 0$ & 12.4 & 12.1 & 15.5 & 11.3 & 12.5 & 11.5 & 19.8 & 28.6 \\
\hline $16: 1(n-7)$ & 0.9 & 0.9 & 2.3 & 0.9 & 0.7 & 0.6 & 0.6 & 1.5 \\
\hline $16: 1(n-5)$ & - & - & - & 11.1 & 0.5 & 1.6 & - & - \\
\hline $16: 2(n-4)$ & - & - & - & - & 0.1 & - & - & - \\
\hline $16: 3(n-4)$ & - & - & - & - & - & - & - & - \\
\hline $16: 4(\mathrm{n}-1)$ & - & - & - & - & - & 0.1 & - & - \\
\hline $18: 0$ & - & 0.2 & 0.3 & 0.3 & 0.5 & 0.1 & 0.7 & 0.1 \\
\hline $18: 1(n-9)$ & 5.3 & 4.8 & 5.1 & 6.7 & 4.7 & 7.0 & 10.7 & 1.7 \\
\hline $18: 1(n-7)$ & - & - & 0.7 & 0.5 & 0.3 & 0.1 & 2.1 & 20.9 \\
\hline $18: 2(n-6)$ & 7.3 & 8.8 & 5.7 & 5.2 & 10.1 & 3.6 & 22.3 & 6.3 \\
\hline $18: 3(n-3)$ & 9.8 & 10.5 & 11.3 & 11.4 & 24.8 & 8.0 & 23.7 & 26.1 \\
\hline $18: 4(n-3)$ & 26.8 & 23.7 & 15.7 & 13.3 & 13.4 & 21.2 & 2.8 & 2.1 \\
\hline $20: 4(n-6)$ & 10.8 & 12.5 & 8.1 & 10.4 & 14.6 & 14.6 & 5.2 & 2.4 \\
\hline $20: 4(n-3)$ & 1.1 & 1.2 & 3.0 & 1.2 & 0.7 & 0.7 & 0.7 & 0.4 \\
\hline $20: 5(n-3)$ & 19.3 & 17.6 & 25.0 & 21.8 & 13.2 & 25.4 & 5.0 & 8.4 \\
\hline $22: 6(n-3)$ & - & - & - & - & - & - & 0.9 & - \\
\hline SAFA & 17.7 & 18.6 & 21.2 & 17.2 & 16.3 & 16.4 & 24.9 & 30.1 \\
\hline MUFA & 6.2 & 5.7 & 8.1 & 19.2 & 6.3 & 9.3 & 13.5 & 24.1 \\
\hline PUFA & 75.1 & 74.3 & 68.6 & 63.3 & 76.9 & 74.3 & 60.8 & 45.7 \\
\hline$(n-6)$ FA & 18.1 & 21.3 & 13.7 & 15.6 & 24.7 & 18.2 & 27.6 & 8.7 \\
\hline$(n-3) F A$ & 57.0 & 53.0 & 54.9 & 47.7 & 52.1 & 55.2 & 33.3 & 37.1 \\
\hline$(n-3) /(n-6)$ & 3.2 & 2.5 & 4.0 & 3.1 & 2.1 & 3.0 & 1.2 & 4.3 \\
\hline
\end{tabular}

$(0.5 \%)$. The percentage of 18:2(n-6) and 18:3(n-3) were 2 times higher in the gametophytes (10.1 and $24.8 \%$, respectively) than in the sporophytic plants. The latter contained $22.8 \%$ of $20: 5(n-3)$, whereas gametophytes contained only $13.2 \%$. The fatty acid composition of sporophytes of D. muelleri and D. antarctica were similar, except for 16:1(n-5), which was low in D. antarctica (Table 4).

\section{Chlorophyta}

The major fatty acids of the 2 Chlorophyta, Prasiola crispa from the Arctic and Lambia antarctica from Antarctica were $18: 3(\mathrm{n}-3)$ (23.7 and $26.1 \%$, respectively) and 16:0 (19.8 and 28.6\%) in both species. In P. crispa, 18:2(n-6) was of similar abundance with $22.3 \%$, whereas in L. antarctica 18:1(n-7) accounted for $20.9 \%$. The (n-3) to (n-6) ratios were low (1.2 and 4.3: Table 4). In the Phaeophyta and Rhodophyta these $\mathrm{C}_{18}$ unsaturated fatty acids represented less than $10 \%$ on average or were only minor components. The high proportion of $\mathrm{C}_{18}$ polyunsaturates in the Chlorophyta was unique for all macroalgae studied.

\section{DISCUSSION}

The amount of polyunsaturated fatty acids in marine macroalgae from Arctic and Antarctic regions was extremely high, in some cases 60 to $80 \%$ of the total fatty acids. These levels are much higher than those reported for macroalgae from lower latitudes (Khotimchenko \& Vaskovsky 1990, Aknin et al. 1992, Banaimoon 1992, Fleurence et al. 1994, Khotimchenko 1998). The principal unsaturated fatty acids were $C_{18}$ and $\mathrm{C}_{20}$ polyunsaturates, whereas $\mathrm{C}_{22}$ polyunsaturates, which are abundant in many phytoplankton species (e.g. Harrington et al. 1970), were only trace components or even nonexistent in the macroalgae.

Within the main taxonomic classes, Rhodophyta, Phaeophyta and Chlorophyta, we found clear differences in the fatty acid composition. The major polyunsaturated fatty acids of the Rhodophyta were 20:5(n-3) and partly 20:4(n-6), and those of the Phaeophyta 20:5(n-3) and 18:4(n-3), while 18:3(n-3) was dominant in the Chlorophyta. These results correspond well with the fatty acid composition of macroalgae from temperate and tropical regions (Khotimchenko \& Vaskovsky 1990, Banaimoon 1992, Fleurence et al. 1994). In the 
Rhodophyta from Arctic and Antarctic regions we found some exceptions from the general fatty acid composition of this class. Although 20:5(n-3) is a major component in many Rhodophyta (Banaimoon 1992, Fleurence et al. 1994), the values (50 to $70 \%$ ) found in Palmaria palmata, Audouinella purpurea, Palmaria decipiens and Myriogramme smithii were extremely high. The Arctic Phycodrys rubens and the Antarctic Delesseria lancifolia contained exceptionally high levels of 20:4(n-6) (>30\%), whereas Rhodophyta from other regions contain only 2 to $15 \%$ of this fatty acid (Khotimchenko \& Vaskovsky 1990). Some Arctic and Antarctic species were also rich in 16:1(n-7), a component that usually contributes only 0.3 to $4 \%$ of the total fatty acids in red macroalgae (Fleurence et al. 1994). In addition, the elevated occurrence of 16:4(n-1) in 2 Antarctic Rhodophyta, particularly in Pantoneura plocamioides $(13.1 \%)$, is striking, since this fatty acid is missing from temperate and tropical taxa (Arao \& Yamada 1989, Khotimchenko \& Vaskovsky 1990, Banaimoon 1992, Fleurence et al. 1994).

There were also considerable differences in the fatty acid composition of the closely related Arctic species Phycodrys rubens and Ptilota gunneri, which often grow in close association at depths of $<12 \mathrm{~m}$ the in Arctic Kongsfjord. The predominant fatty acid in $P$. rubens was 20:4(n-6) and in P. gunneri 16:1(n-7). Clear compositional differences were also found between the Arctic Palmariales Devaleraea ramentacea and Palmaria palmata, also growing at similar locations in shallow waters of the Kongsfjord. We therefore conclude that these conspicuous differences in fatty acid compositions between species within the same order and growing in the same habitat are species-specific rather than being related to environmental factors or depth distribution. Thus, it seems possible to distinguish closely related Rhodophyta species by their fatty acid composition.

Despite their different distribution, the Phaeophyta from the Arctic, Antarctica and sub-Antarctica had a similar fatty acid composition, dominated by 18:4(n-3), 20:5(n-3) and 20:4(n-6). The same fatty acids, but in varying proportions, have been determined in many species of this class from other regions (Fleurence et al. 1994, Khotimchenko 1995b, 1998, Herbreteau et al. 1997). In addition, the gametophytes of Desmarestia muelleri had high amounts of 18:3(n-3), whereas the sporophytes were characterised by a considerable proportion of 16:1(n-5). In contrast, sporophytes of $D$. antarctica had only low levels of this fatty acid. 16:1(n-5) is considered an uncommon fatty acid in macroalgae, although it occurs in small amounts of $3 \%$ in the closely related Desmarestia ligulata from temperate waters, and in amounts up to $14 \%$ in Dictyota ciliata from the tropics (Aknin et al. 1992, Khotimchenko 1995b, 1998). This is the first report of such striking biochemical differences in the fatty acid composition of different life-history stages of one macroalgal species.

The fatty acid composition of macroalgae is known to be influenced by environmental factors such as light intensity, salinity and temperature (Levy et al. 1992, Floreto \& Teshima 1998). Ecophysiological parameters, such as sensitivity of photosynthetic performance under light stress, or pigment content, also differ significantly between gametophytes and sporophytes of Laminaria saccharina (Hanelt et al. 1997) and Desmarestia menziesii (Gómez \& Wiencke 1996). The different fatty acid content of sporophytes and gametophytes of $D$. muelleri is another example of different metabolic characteristics at different life history stages.

The fatty acid composition of the Arctic Chlorophyta Prasiola crispa and the Antarctic Lambia antarctica differed significantly from that of the other taxa in their high abundance of $\mathrm{C}_{18}$ unsaturated fatty acids and relatively low levels of 20:5(n-3). The fatty acid composition found here corresponds to the composition of temperate and tropical Chlorophyta (Banaimoon 1992, Herbreteau et al. 1997), but their proportions are clearly different. The chlorophytes of the genus Caulerpa, and the species Enteromorpha intestinalis and Ulva rotundata (Fleurence et al. 1994, Khotimchenko 1995a), contain lower proportions of 18:1(n-7) than $L$. antarctica, and the proportions in P. crispa are also low. In addition, $P$. crispa has higher levels of the fatty acid 18:2(n-6) than L. antarctica and the other Chlorophyta. The data for these quantitative differences are probably too fragmentary to distinguish between polar Chlorophyta or between polar species and species from other regions on the basis of fatty acids.

The reason for the distinct differences in fatty acid composition between the 3 taxa Rhodophyta, Phaeophyta and Chlorophyta may be their different evolution. There has been a tendency over the past $30 \mathrm{yr}$ to consider Rhodophyta as the most 'primitive' eukaryotes (Taylor 1978) because of the presence of phycobiliprotein pigments and their arrangement in phycobilisomes, which are typical features of ancient cyanobacteria. Chlorophyta are undoubtedly the closest relatives of higher plants, and hence the most 'modern' macroalgae. The Phaeophyta were thought to have a phylogenetic position between Rhodophyta and Chlorophyta. However, modern molecular approaches indicate a closer relationship between Rhodophyta and Chlorophyta (van den Hoek et al. 1995). Although the phylogenetic relationship between Rhodophyta, Phaeophyta and Chlorophyta is still under debate, the data presented here point to taxa-specific biosynthetic pathways for fatty acids (Fig. 1) that may help to clarify the open questions. 
(n-6) family (n-3) family

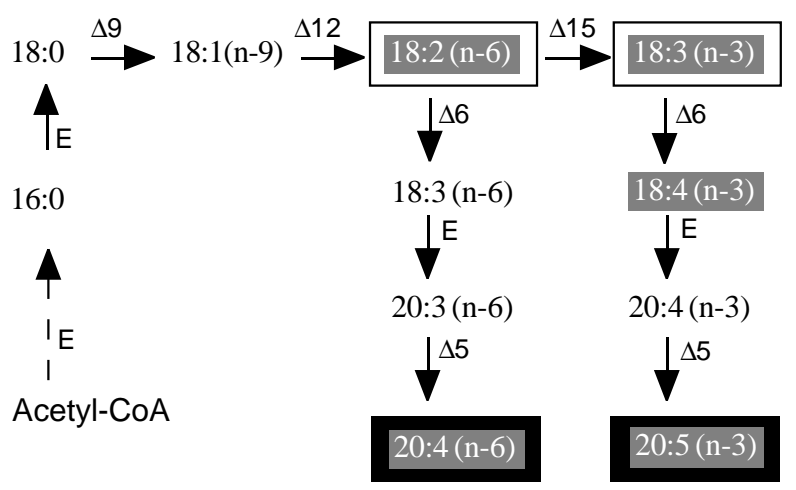

Fig. 1. Major pathways and accumulation of polyunsaturated fatty acids in plants (Gurr \& Harwood 1991). Grey: Rhodophyta; black: Phaeophyta; white: Chlorophyta; E: elongation; $\Delta$ : desaturases

Rhodophyta and Phaeophyta exhibit the highest amounts of the $\mathrm{C}_{20}$ polyunsaturated fatty acids, and Rhodophyta the highest proportions of 20:5(n-3) and partially of 20:4(n-6). We therefore conclude that their presence reflect a more 'marine'-like and hence more ancestral character. This hypothesis is well supported by the fact that, according to fossil records and molecular data, Rhodophyta are the phylogenetically oldest lineage within the macroalgae (van den Hoek et al. 1995). In the Phaeophyta, the fatty acid 18:4(n-3) is as dominant as 20:5(n-3), supporting the intermediate position of this taxon between Rhodophyta and Chlorophyta. It is noteworthy that the intermediate products, 20:3(n-6) and 20:4(n-3), which result from chain elongation, are only minor components or are lacking. They are immediately converted by the delta- 5 desaturase to the major end products (Fig. 1). In contrast to Rhodophyta and Phaeophyta, Chlorophyta contain primarily $\mathrm{C}_{18}$ unsaturated fatty acids typical of vegetative tissue of higher plants. In Rhodophyta and Phaeophyta, competition between fatty acids of the (n-6) and (n-3) family may occur. As 18:3(n-3) represents the better substrate for the delta- 6 desaturase than 18:2(n-6), it can therefore effectively decrease the formation of 20:4(n-6) from 18:2(n-6) (Cook 1991), resulting in higher proportions of 20:5(n-3). Chlorophyta probably lost the general ability to convert $\mathrm{C}_{18}$ polyunsaturated fatty acids to $\mathrm{C}_{20}$ polyunsaturated fatty acids during evolution to avoid competition between (n-6) and (n-3) fatty acids. This reduction may be regarded as an 'advanced' phylogenetic character.

Comparing the Arctic and Antarctic marcoalgae we found no unequivocal differences in their fatty acid composition, although both regions differ markedly in their cold-water history. While continental glaciation in the Arctic started in the Pliocene 3 to $5 \mathrm{Ma}$, in Antarctica the first glaciers at sea level appeared in the Oligocene $14 \mathrm{Ma}$ (reviewed by Lüning 1990). In addition, specific oceanographic conditions cause a more pronounced geographical isolation of Antarctica than the Arctic, resulting in a macroalgal flora of which onethird is composed of endemic species. In contrast, the Arctic macroalgal flora consists mainly of a reduced North Atlantic flora with few endemic species. The lipid composition is quite similar in endemic and nonendemic macroalgae of both polar regions. However, many polar macroalgae differ in their fatty acid composition from those of temperate and tropical species. Whether these differences are attributable to latitudinal and/or habitat-specific adaptations, e.g. to guarantee the fluidity of membranes at low temperatures, is still unresolved.

Information on the benthic food web structure of polar regions is essential for understanding the foodweb structures and functions (e.g. algal productivity, fate of biomass, grazing pressure and anti-grazing strategies) under extreme environmental conditions. In studies on trophic relationships, microscopical gutcontent analysis of herbivores were carried out to identify the macroalgal species consumed (Iken et al. 1997, Iken 1999, Ojeda \& Munoz 1999), but this is only possible during the early stages of digestion. Another approach is multiple stable-isotope analysis (Loneragan et al. 1997). While this technique allows differentiation between the main groups of primary producers, all macroalgal species exhibit a very similar isotopic signature. Fatty acids, on the other hand, seem to be a promising tool for studying trophic relationships in polar waters, since the lipid composition of macroalgae is made up largely of characteristic polyunsaturated fatty acids.

Acknowledgements. The authors would like to thank Corinna Harms, Christina Langreder, Claudia Daniel and Angelika Dummermuth for technical assistance in cultivating algae and analyses. This project was partially supported by the Deutsche Forschungsgemeinschaft (Ha 1706/6-1, Ka 899/6-1, Wi 646/7-1).

\section{LITERATURE CITED}

Aknin M, Dogbevi K, Samb A, Kornprobst JM, Gaydou EM, Miralles J (1992) Fatty acid and sterol composition of eight brown algae from the Senegalese coast. Comp Biochem Physiol B 102:841-843

Amsler DA, McClintock JB, Baker BJ (1998) Chemical defence against herbivory in the Antarctic marine macroalgae Iridaea cordata and Phyllophora antarctica (Rhodophyceae). J Phycol 34:53-59

Arao T, Yamada M (1989) Positional distribution of fatty acids in galactolipids of algae. Phytochemistry (Oxford) 28: 805-810

Banaimoon SA (1992) Fatty acids in marine macroalgae from 
Southern Yemen (Hadramout) including occurrence of eicosatetraenoic (20:4) and eicosapentaenoic (20:5) acids. Bot Mar 35:165-168

Cook HW (1991) Fatty acid desaturation and chain elongation in eucaryotes. In: Vance DE, Vance J (eds) Biochemistry of lipids, lipoproteins and membranes. Elsevier, Amsterdam, p 141-168

Duggins DO, Simensted CA, Estes IA (1989) Magnification of secondary production by kelp detritus in coastal marine ecosystems. Science 245:170-173

Fleurence J, Gutbier G, Mabeau S, Leray C (1994) Fatty acids from 11 marine macroalgae of the French Brittany coast. J Appl Phycol 6:527-532

Floreto EAT, Teshima S (1998) The fatty acid composition of seaweeds exposed to different levels of light intensity and salinity. Bot Mar 41:467-481

Folch J, Lees M, Sloane-Stanley GH (1957) A simple method for the isolation and purification of total lipids from animal tissues. J Biol Chem 226:497-509

Gaines SD, Lubchenco J (1982) A unified approach to marine herbivore interactions. II. Biogeography. Annu Rev Ecol Syst 13:111-138

Gómez I, Wiencke C (1996) Photosynthesis, dark respiration and pigment contents of gametophytes and sporophytes of the Antarctic brown alga Desmarestia menziesii. Bot Mar 39:149-157

Graeve M, Hagen W, Kattner G (1994a) Diet-induced changes in the fatty acid composition of Arctic herbivorous copepods: experimental evidence of trophic markers. J Exp Mar Biol Ecol 182:97-110

Graeve M, Hagen W, Kattner G (1994b) Herbivorous or omnivorous? On the significance of lipid compositions as trophic markers in Antarctic copepods. Deep-Sea Res Part I 41:915-924

Graeve M, Kattner G, Piepenburg D (1997) Lipids in Arctic benthos: does fatty acid and alcohol composition reflect feeding and trophic interactions? Polar Biol 18:53-61

Graeve M, Dauby P, Scalteur Y (2001) Combined lipid, fatty acid and digestive tract content analyses: a penetrating approach to estimate feeding modes of Antarctic amphipods. Polar Biol 24:855-862

Gurr, MI, Harwood JL (1991) Lipid biochemistry-an introduction, 4th edn. Chapman \& Hall, London

Hanelt D, Wiencke C, Karsten U, Nultsch W (1997) Photoinhibition and recovery after high light stress in different developmental and life-history stages of Laminaria saccharina (Phaeophyta). J Phycol 33:387-395

Harrington GW, Beach DH, Dunham JE, Holz Jr GG (1970) The polyunsaturated fatty acids of marine dinoflagellates. J Protozool 17:213-219

Hawkins SJ, Hartnoll RG (1983) Grazing of intertidal algae by marine invertebrates. Oceanogr Mar Biol Annu Rev 21: 195-282

Herbreteau F, Coiffard LJM, Derrien A, de Roeck-Holtzhauer Y (1997) The fatty acid composition of five species of macroalgae. Bot Mar 40:25-27

Iken K (1999) Feeding ecology of the Antarctic herbivorous gastropod Laevilacunaria antarctica Martens. J Exp Mar Biol Ecol 236:133-148

Iken K, Barrera-Oro ER, Quartino ML, Casaux RJ, Brey T (1997) Grazing by the Antarctic fish Notothenia coriiceps:

Editorial responsibility: Otto Kinne (Editor), Oldendorf/Luhe, Germany evidence for selective feeding on macroalgae. Antarct Sci 9:386-391

Jones AL, Harwood JL (1992) Lipid composition of the brown algae Fucus vesiculosus and Ascophyllum nodosum. Phytochemistry (Oxford) 31:3397-3403

Kattner G, Fricke HSG (1986) Simple gas-liquid chromatographic method for the simultaneous determination of fatty acids and alcohols in wax esters of marine organisms. J Chromatogr 361:263-268

Khotimchenko SV (1995a) Fatty acid composition of green algae of the genus Caulerpa. Bot Mar 38:509-512

Khotimchenko SV (1995b) Uncommon 16:1(n-5) fatty acid from Dictyota dichotoma and fatty acids of some brown algae of Dictyotaceae. Phytochemistry (Oxford) 38: 1411-1415

Khotimchenko SV (1998) Fatty acids of brown algae from the Russian Far East. Phytochemistry (Oxford) 49:2363-2369

Khotimchenko SV, Vaskovsky VE (1990) Distribution of $\mathrm{C}_{20}$ polyenoic fatty acids in red macrophytic algae. Bot Mar 33: $525-528$

Klöser H, Quartino ML, Wiencke C (1996) Distribution of macroalgae and macroalgal communities in gradients of physical conditions in Potter Cove, King George Island. Antarctica. Hydrobiologia 333:1-17

Levy I, Maxim C, Friedlander M (1992) Fatty acid distribution among some red algal macrophytes. J Phycol 28:299-304

Loneragan NR, Bunn SE, Kellaway DM (1997) Are mangroves and seagrasses sources of organic carbon for penaeid prawns in a tropical Australian estuary? A multiple stableisotope study. Mar Biol 130:289-300

Lüning K (1990) Seaweeds - their environment, biogeography, and ecophysiology. John Wiley \& Sons, New York

Nelson MM, Phleger CF, Mooney BD, Nichols PD (2000) Lipids of gelatinous antarctic zooplankton: Cnidaria and Ctenophora. Lipids 35:551-559

Nelson MM, Mooney BD, Nichols PD, Phleger CF (2001) Lipids of Antarctic Ocean amphipods: food chain interactions and the occurrence of novel biomarkers. Mar Chem 73:53-64

Ojeda FP, Munoz AA (1999) Feeding selectivity of the herbivorous fish Scartichthys viridis: effects on macroalgal community structure in a temperate rocky intertidal coastal zone. Mar Ecol Prog Ser 184:219-229

Phleger CF, Nichols PD, Virtue P (1998) Lipids and trophodynamics of Antarctic zooplankton. Comp Biochem Physiol B 120:311-323

Provasoli L (1968) Media and prospects for cultivation of marine algae. In: Watanabe A, Hattori A (eds) Cultures and collections of algae. Japanese Society of Plant Physiology, Tokyo, p 47-74

Smith SV (1981) Marine macrophyte as a global carbon sink. Science 211:838-840

Taylor FJR (1978) Problems in the development of an explicit hypothetical phylogeny of the lower eucaryotes. Biosystems 10:67-89

van den Hoek C, Mann DG, Jahns HM (1995) Algae-an introduction to phycology. Cambridge University Press, Cambridge

Wiencke C (1990) Seasonality of brown macroalgae from Antarctica - a long-term culture study under fluctuating Antarctic daylengths. Polar Biol 10:589-600

Submitted: July 2, 2001; Accepted: October 30, 2001

Proofs received from author(s): March 27, 2002 